UDK BROJEVI: 613.86:331.08;

159.944.4.07:331.08

МЕТОДОЛОГИЈА ИСТРАЖИВАЊА ПРОФЕСИОНАЛНОГ СТРЕСА

КОД РАДНИКА ЗАПОСЛЕНИХ НА РАДНИМ МЕСТИМА СА

ПОВЕҺАНИМ РИЗИКОМ ПО ЗДРАВЉЕ*

Љиљана Кулић ${ }^{1}$, Миливоје Гаљак ${ }^{2}$, Миљан Кулић ${ }^{3}$ Страхиња Кулић ${ }^{4}$, Срђан Станковић ${ }^{5}$, Јована Кулић

\title{
METHODOLOGY OF RESEARCH ON PROFESSIONAL STRESS AMONG WORKERS EMPLOYEED IN WORKPLACES WITH INCREASED HEALTH RISK
}

Ljiljana Kulić, Milivoje Galjak, Miljan Kulić, Strahinja Kulić, Srđan Stanković, Jovana Kulić

*Рад је резултат истраживања на научно-истражсивачком Јуниор пројекту: „Професионални стрес и морбидитет радника запослених на радним местима са повећаним ризиком по здравље Северног дела Косова и Метохије“, који је непрофитан, реализује га Универзитет у Приштини, Медицински факултет са седиштем у Косовској Митровици, изиклус научних истраживања у периоду 2015-2020. године.

\section{Сажетак}

Увод: Неке професије су нешто вите изложене стресу и већ дуже време су предмет истраживања: юихови радни услови, појава стреса и юегов утииај на юихово здравље. Посебан значај има истраживане професионалног стреса код запослених на радним местима са посебним ризиком по здравље.

Циљ рада је да укаже на методолошки приступ код истражсивана професионалног стреса код радника запослених на радним местима са повећаним ризиком по здравље.

Метод рада: Анализирани су подащи и литература у области медицине рада, интерне медицине, психологије, неуропсихијатрије, јавног здравља, квалитета живота и здравствене статистике у делу који се односи на утицај стреса на здравље човека, са посебним акиентом на методологију која се примењује при сповођењу ових истраживања.

\section{Summary}

Introduction: Some professions are somewhat more exposed to stress and their working conditions are a subject of research for a long time, along with the occurrence of stress and its impact on their health. Research on professional stress among employees at workplaces with special health risks is of special importance.

The aim of the paper is to point out the methodological approach to the research of professional stress among workers employed in workplaces with increased health risk.

Methods: We analyzed the data and literature in the field of occupational medicine, internal medicine, psychology, neuropsychiatry, public health, quality of life and health statistics in the part relating to the impact of stress on human health, with particular emphasis on the methodology to be applied in pursuance these investigations.

Results and discussion: Law on safety and health at work (,, Official Gazette of the Republic of Serbia“" No 101/05) and Rule book on the manner and procedure of risk assessment at the workplace and working environment (,Official Gazette of the Republic of Serbia", No 72/06) still do not have a measurement of the level of stress at work among the existing methods for risk assessment. The fact is that concern for the mental health of employees is not a luxury but a professional obligation of

\footnotetext{
1 Доц. др Љиљана Кулић, Универзитет у Приштини, Медицински факултет, Косовска Митровица.

2 Др спец. Миливоје Гаљак, Дом здравља Звечан, на докторским студијама, Медицински факултет, Косовска Митровица.

${ }^{3}$ Миљан Кулић, дипл. ек., на мастер студијама, Београд.

${ }^{4}$ Мр Страхиња Кулић, дипл. ек., на докторским студијама, ПИО фонд, Београд.

${ }^{5}$ Мр Срђан Станковић, дипл. правник, Електромрежа Србије, Београд.

${ }^{6}$ Мр Јована Кулић, дипл. инж. менаџмент и организација, на докторским студијама, Београд.
} 
Резултати рада и дискусија: Закон о безбедности и здрављу на раду, „Службени гласник РС“, број 101/05. и Правилник о начину и поступку процене ризика на радном месту и у радној околини. „Службени гласник РС“, број 72/06, међу постојећим методама за проиену опасности, још увек немају мерење нивоа стреса на раду. Чињеница је да брига за ментално здравље запослених није луксуз већ професионална обавеза послодаваца. Методе коришћене за процену стреса на раду могу бити субјективне, објективне и интермедијарне. Субјективне методе су упитници, односно самопрочена, где радниции оценьују ниво сопствених тегоба, захтеве и тежину свог посла, међуљудске односе и др. Објективне методе подразумевају одређивање нивоа кортизола и катехоламина у урину. Интермедијарне методе су делимично субјективне и у юих спада разговор са другим радницима, анализа боловаға, анализа радних места са повећаним ризиком, анализа продуктивности, повређивана на раду, најчешћих болести међу групом запослених, разговор са претпостављенима, разговор са менаиментом фирме и др. Да би се проиенио субјективни доживљај стреса на радном месту и идентификовали стресори, користи се вите врста упитника. У свим истраживањима неопхоно је узимање основних података о испитаницима, а за то су већ дизајнирани одговарајући упитници, тзв. Упитник о основним социодемографским показатељима испитаника. Поред юега неопходно је користити Упитник за одређивање индекса радне способности (енгл. Work Ability Index Questionnaire), који је добар инструмент за процену радне способности. IRS Questionnaire је упитник за процену извора стреса на раду. Општи здравствени упитник (General Health Questionnsire - GHQ, Goldberg D,Williams $P$, 1991) мери осећај напетости, депресије, неспособности за одбрану, несанищу засновану на анксиозности, недостатак самопоуздана и самопоштована и друге симптоме поремећаја психичког функиионисана. Copenhagen Burnout Inventory (CBI) employers. Methods used to evaluate stress at work can be subjective, objective and intermediate. Subjective methods are questionnaires or self-evaluation, where workers evaluate the level of their own problems, demands and the weight of their work, interpersonal relations, etc. Objective methods include determining the level of cortisol and catecholamines in urine. Intermediate methods are partly subjective and include talking with other workers, the analysis of sick leaves, analysis of workplaces with increased risk, productivity analysis, injuries at work, the most common diseases among a group of employees, an interview with superiors, company management and others. To assess the subjective experience of stress in the workplace and identify stressors, many types of questionnaires are being used. In all studies, it is necessary to take basic data about the respondents, and appropriate questionnaires already designed, so-called Respondents' $\mathrm{Ba}$ sic Demographic Indicators Questionnaire. In addition, it is necessary to use the Work Ability Index Questionnaire, which is a good instrument for the assessment of work capacity. IRS Questionnaire is used for assessing the sources of stress at work. General Health Questionnsire - GHQ (Goldberg, D, Williams, P, 1991) measures the feeling of anxiety, depression, inability to defend, insomnia based on anxiety, lack of self-confidence and self-esteem and other symptoms of psychological disorders functioning. Copenhagen Burnout Inventory (CBI) is a questionnaire that includes tests relating to personal burnout, burnout at work and client burnout. Study is based on modern methods of statistical data processing. The use of these questionnaires provides a comparison of our results with the results of the research of other domestic and foreign researchers.

Conclusion: It is necessary that specific working conditions, the occurrence of stress and its impact on health become a subject of more extensive research, with specially designed questionnaires. Not all questionnaires can be used in any working population, because the factors that cause stress differ in type, scale and duration. It is necessary to adapt the set of 
је упитник који укључује испитивања која се односе на персонално изгарање, изгарање на раду и клијент изгарање. У истраживању се примењују савремене методе статистичке обраде података. Употреба ових упитника омогућава упоређивағе добијених резултата са резултатима истраживања осталих истраживача код нас и у свету.

Закључак: Неопходно је да специфични радни услови, појава стреса и његов утииај на юихово здравље буду предмет опсежнијих истраживања, са посебно дизајнираним упитницима. Не могу се сви упитници користити код било које радне популације, јер су и фактори који доводе до појаве стреса разликују и по врсти, по интензитету $и$ по трајању. Неопходно је да се сет упитника прилагоди за одговарајуће врсте делатности, тако да поред општих упитника буду коришћени и они који дају прецизне резултате приликом проиене стреса у појединим професијама. Употреба одговарајуће групе упитника код истраживања професионалног стреса код радника запослених на радним местима са повећаним ризиком по здравље омогућава добијање валидних резултата и омогућава упоређиване добијених резултата са резултатима одговарајућих истраживања код нас и у свету.

Кључне речи: професионални стрес, упитници, радници, ризик по здравље. questionnaires to respective type of activity, so that those that provide accurate results when assessing stress in certain professions can be used next to the general questionnaires. Usage of the appropriate sets of questionnaires in research of professional stress among workers employed in workplaces with increased health risk enables getting valid results and allows comparison of the obtained results with the results of relevant domestic and foreign research.

Key words: professional stress, questionnaires, workers, health risk.

\section{УВОД}

И страживања усмерена на утврђивање штетности и опасности на радном месту и у радној околини које могу да узрокују повреду на раду и/или професионално обољење су увек актуелна, a једна од најактуелнијих штетности на радном месту је стрес. Оно што је од стране свих истраживача стреса прихваћено је да је он општа неспецифична реакција организма изазвана неповољним утицајима из спољне и унутрашње средине, а да је професионални стрес везан за делатност. У већини занимања присутни су општи стресори, а у појединим занимањима уз опште стресоре појављују се и специфични, који су карактеристични управо за то занимање. Општи стресори укључују сменски рад, лошу организацију, висок ниво одговорности уз малу могућност утицаја на рад, немогућност трајног професионалног образовања, премало радника и међуљудске сукобе. За поједина занимање постоје поред 
њих и специфични стресори везани уз радне задатке, услове рада и начин обављања посла управо у тим занимањима. ${ }^{(1)}$

Неке професије су нешто више изложене стресу и већ дуже време су предмет истраживања: њихови радни услови, појава стреса и његов утицај на здравље. Посебан значај има истраживање професионалног стреса код запослених на радним местима са посебним ризиком по здравље. Иако се зна да су неке материје опасне, врло је тешко избећи контакт са њима у неком сегменту радног процеса. Опасне материје су експлозивне, запаљиве, оксидирајуће, отровне, заразне, корозивне, канцерогене и радиоактивне материје утврђене стандардима и другим прописима, а које се производе, користе или складиште у процесу рада, као и материје чија су својства, када су везане за неке супстанце, опасна по живот и здравље запослених. У раду са опасним материјама постоји ризик, односно вероватноћа настанка повреде, обољења или оштећења здравља запосленог услед опасности. У систему безбедности и здравља на раду послодавац је дужан да донесе акт о процени ризика, односно да утврди која су то радна места са повећаним ризиком, а која не. Радно место са повећаним ризиком је радно место утврђено актом о процени ризика на коме, и поред потпуно или делимично примењених мера у складу са овим законом, постоје околности које могу да угрозе безбедност и здравље запосленог. Без обзира на коришћење заштитних средстава и примену одговарајућих мера заштите, опасност и ризик нису потпуно елиминисани, а једна од доказаних штетности која је присутна због рада у оваквим околностима је стрес. ${ }^{(2)}$

Рад радника на радним местима са повећаним ризиком по здравље је погодно тле за настанак негативних емоционалних реакција и стања услед изложености двострукој врсти притиска. Са једне стране, налазе се сложени радни задаци и често лоши услови рада са присутним физичким и хемијским штетним ноксама, а са друге стране је захтев за скоро апсолутном тачношћу, за одговарајући учинак и постизање резултата рада који су нормирани и повезани са економском надокнадом, при чему грешка може да доведе до тешких последица по здравље и живот радника.

\section{ЦИЉ РАДА}

Циљ рада је да укаже на методолошки приступ код истраживања професионалног стреса код радника запослених на радним местима са повећаним ризиком по здравље.

\section{МЕТОД РАДА}

Анализирани су подаци и литература у области медицине рада, интерне медицине, психологије, неуропсихијатрије, јавног здравља, квалитета живота и здравствене статистике у делу који се односи на утицај стреса на здравље човека, са посебним акцентом на методологију која се примењује при сповођењу ових истраживања.

\section{РЕЗУЛТАТИ РАДА И ДИСКУСИЈА}

Савремена медицина рада учествује у процени ризика радних места сходно правилнику и закону о безбедности и здрављу на раду. У складу са тим законску обавезу израде процене ризика на радном месту у Републици Србији имају послодавци у делатности индустрије, рударства, грађевинарства, пољопривреде, рибарства, шумарства, саобраћаја, здравства и других делатности у којима постоје фактори штетни по здравље. ${ }^{(2,3)}$

У складу са одредбом члана 43 Закона о безбедности и здрављу на раду („Сл. гласник PC“, број 101/2005 - даље: Закон) прописана је обавеза послодавца да запосленом на радном месту са повећаним ризиком пре почетка рада обезбеди претходни лекарски преглед, као и периодични лекарски преглед у току рада. Иако запослени приликом ступања у радни однос пролазе кроз обавезне систематске прегледе, неопходно 
је да они који раде на местима с повећаним ризиком треба да иду на периодичне контролне прегледе, како би се на време открила и спречила опасност од могуће болести. Претходни и периодични лекарски прегледи запослених на радним местима са повећаним ризиком врши служба медицине рада на начин, по поступку и у роковима утврђеним прописима о безбедности и здрављу на раду, које споразумно прописују министар надлежан за рад и министар надлежан за здравље. Одредбама Закона прописана је дужност послодавца да обезбеди прописане лекарске прегледе у ситуацији када је послодавац актом о процени ризика утврдио да је неко радно место радно место са повећаним ризиком за здравље запосленог. Периодични лекарски преглед се врши ради праћења и оцењивања здравственог стања, односно способности запосленог за обављање послова на радном месту са повећаним ризиком на коме запослени ради или за употребу односно руковање одређеном опремом за рад, у односу на факторе ризика тог радног места, а у роковима прописаним одговарајућим правилником. Запослени треба да се упућује на периодични лекарски преглед шест месеци, на годину дана, на две године, што зависи од опасности и штетности. Када је неко радно место проглашено за радно место са повећаним ризиком, запослени је обавезан да се одазове на преглед, а послодавац има обавезу да га на те прегледе упути. Ако се у поступку периодичног лекарског прегледа утврди да запослени не испуњава посебне здравствене услове за обављање послова на радном месту са повећаним ризиком, послодавац је дужан да га премести на друго радно место, које одговара његовим здравственим способностима. Неиспуњавање посебних здравствених услова за рад на радном месту са повећаним ризиком не може бити разлог за отказ уговора о раду. У лекарском извештају може да се наведе само да је запослени способан за рад или да није, али не и од чега запослени болује, јер то спада у лични здравствени податак. То је стандард Европске уније, а уведено је и као стандард у нашим прописима, јер може изазвати дискриминацију по том основу ако неко болује од неке болести, а то послодавцу не одговара. За запослене који не раде на радном месту са повећаним ризиком у вези са здравственим сметњама примењује се одредба члана 81 Закона о раду („Сл. гласник РС“, број 24/2005, 61/2005, 54/2009, $32 / 2013$ и 75/2014). ${ }^{(4)}$

Закон о безбедности и здрављу на раду, „Службени гласник РС“, број 101/2005. и Правилник о начину и поступку процене ризика на радном месту и у радној околини. „Службени гласник РС“, број 72/2006 међу постојећим методама за процену опасности, још увек немају мерење нивоа стреса на раду. Чињеница је да брига за ментално здравље запослених није луксуз већ професионална обавеза послодаваца. Послодавци који се брину о својим запосленима морају планирати и спроводити организационе мере за спречавање и смањивање радног стреса.

Методе коришћене за процену стреса на раду могу бити субјективне, објективне и интермедијарне.

- Субјективне методе су упитници, односно самопроцена, где радници оцењују ниво сопствених тегоба, захтеве и тежину свог посла, међуљудске односе и др.

- Објективне методе подразумевају одређивање нивоа кортизола и катехоламина у урину.

- Интермедијарне методе су делимично субјективне и у њих спада разговор са другим радницима, анализа боловања, анализа радних места са повећаним ризиком, анализа продуктивности, повређивања на раду, најчешћих болести међу групом запослених, разговор са претпостављенима, разговор са менаџментом фирме и др. ${ }^{(5)}$ 
Резултати истраживања указују да исти стресор различити људи могу доживети на различит начин, различитим интензитетом, a да је при томе веома важан однос појединца према сваком од њих. Да би се проценио субјективни доживљај стреса на радном месту и идентификовали стресори, користи се више врста упитника. ${ }^{(6,7,8)}$

У свим истраживањима неопходно је узимање основних података о испитаницима, а за то су већ дизајнирани одговарајући упитници, који се могу користити и приликом спровођења истраживања професионалног стреса код радника запослених на радним местима са повећаним ризиком по здравље. Упитник о основним социодемографским показатељима испитаника - садржи генералије, основне податке о полу, добној групи (старости), брачном статусу, начину становања, врсти посла, висини прихода, евентуалној употреби алкохола, цигарета и седатива и др. социодемографским показатељима.

У истраживању стреса на раду код запослених, неопходно је препознавање и оцењивање интензитета фактора стреса на раду и утицаја стреса на радну способност. Оцењивање радне способности је поступак на основу кога се врши усклађивање биолошке функције организма са захтевима, ризицима и карактеристикама радног места и законодавним прописима. Различите државе у свету имају различити приступ изради закона и прописа у области радне способности и њиховом спровођењу у пракси. Земље чланице Европске уније имају у своје национално законодавство уграђен низ директива које успостављају минималне стандарде у области процене и заштите радне способности. Ове директиве, којих има око 20 у разним областима, прати слична структура захтева за послодавца да непрекидно процењују ризике радног места и ставе на прво место превентивне мере засноване на хијерархији контроле, укључујући у те активности у непрекидну процену радне способности. ${ }^{(9)}$ Радна спо- собност је дефинисана као способност радника за обављање својег посла узевши у обзир специфичне радне захтеве, радникову здравствену способност и његове психичке могућности. Оцењивање радне способности (OPC) поступак је који има за циљ да се на основу биолошких функција организма радника и биолошких захтева радног места процени које је послове испитивана особа способна да обавља. За адекватну процену радне способности (РС) потребно је детаљно познавати психофизичке (биолошке) способности испитаника, као и услове и ризике на радном месту и захтеве радног места, а затим ускладити податке из ове две групе. Познавање ризика на послу, услова и захтева радног места неопходно је за валидну процену радне способности, јер много утиче на доношење суда о радној способности. Након добијања података, потребно је њихово усклађивање и доношење закључака о радној способности. Упитник за одређивање индекса радне способности (енгл. Work Ability Index Questionnaire) омогућава да се израчуна показатељ радне способности, тзв. индекс радне способности (енгл. Work Ability Index), у даљњем тексту WAI. WAI упитник има широку примену у свакодневној пракси и у научним истраживањима у медицини рада и досадашња истраживања с подацима о валидности и поузданости теста показала су да је WAI упитник добар инструмент за процену радне способности. Коришћен је за идентификацију ризичних фактора који доводе до смањења радне способности и као метода избора за процену учинака интервенцијских програма за побољшање радне способности и отклањање чиниоца смањене радне способности или у истраживачке сврхе као идентификатор групе која би била циљна за превентивне програме везане за здравље на раду. Примена овог једноставног инструмента је у процени радне способности појединца на периодичним прегледима. Осим тога примењује се за мерење радне способности свих радника појединих делова предузећа у процени 
радних места. Поређењем тих резултата са референтним вредностима, специјалиста медицине рада може одредити које мере je потребно предузети за унапређење индивидуалне радне способности. WAI је јако добар прогностички показатељ: радници који имају ниске вредности WAI-a напуштају посао у раздобљу од пет година било пензионисањем или променом радног места. ${ }^{(10,11)}$ Упитник за одређивање индекса радне способности (енг. Work Ability Index Questionnaire); у даљњем тексту WAI Упитник, јесте стандардизирани упитник Финског института за медицину рада. Користи се за испитивање радне способности у релацији са захтевима посла. Индекс радне способности (енг. WAI) се изражава нумерички и израчунава се према упутствима Финског института за медицину рада. Распон бодова је од 7 до 49 бодова. Већи број бодова означава бољу радну способност. Према броју бодова Индекс радне способности је рангиран у четири категорије: лош (од 7 до 27 бодова); добар (од 28 до 36 бодова); врло добар (од 37 до 43 бода) и изврстан (од 44 до 49 бодова).

IRS Questionnaire је упитник за процену извора стреса на раду. Упитник процењује како запослени доживљавају свој посао и у њему су наведени догађаји који су присутни на послу многих људи. Испитаник треба пажљиво да прочита сваку тврдњу и заокружи онај одговор који најбоље описује колико је сваки од догађаја присутан на његовом послу. Скала има 42 ставке, а формат одговарања је Ликертова петостепена скала (,сккоро никад“, „ретко“, „понекад“, „често“ и „скоро увек“). Бројеви имају следеће значење: 1 - скоро никад, 2 ретко, 3 - понекад, 4 - често и 5 - скоро увек. Садржи седам супскала које процењују различите изворе стреса у организацији (захтеви посла, контрола, подршка од стране руководиоца, подршка колега, релације и радна атмосфера, радна улога, промене), али за потребе истраживања биће коришћено алтернативно скоровање, при коме је формиране супскала позитивних догађаја (пример „Имате довољно могућности да са руководством разговарате о променама на послу.“) и супскала негативних догађаја (пример „Ваш посао захтева да радите веома брзо.“). Обе супскале имају по седам ставки. Класификација догађаја из упитника IRS на позитивне и негативне биће урађена објективно, тј. догађаји ће бити сврстани у одговарајуће супскале од стране истраживача.

Општи здравствени упитник (General Health Questionnsire - GHQ, Goldberg D, Williams P, 1991) мери осећај напетости, депресије, неспособности за одбрану, несаницу засновану на анксиозности, недостатак самопоуздања и самопоштовања и друге симптоме поремећаја психичког функционисања. Постоје четири варијанте овог упитника, а варијанта GHQ-12, која ће бити коришћена у овом истраживању, препоручена је за мерење психолошког дистреса. Тест садржи 12 ставки (ајтема) на која су понуђена четири градирана одговора (боље него обично, исто као и обично, мање него обично, много мање него обично). У овом раду користили смо би-модални метод скоровања (0-0-1-1), у складу са званичним приручником. Максимални скор (број бодова на тесту) је 12, а могући опсег 0-12. Скор од 4 и већи, значи могуће присуство психичког дистреса, а скор од 8 и већи значи сигурно присуство различитих симптома психичких поремећаја изазваних стресом.

\section{Copenhagen Burnout Inventory (CBI)} - је упитник норвешких аутора који је у употреби од 2004. године. Састоји се од 19 ставки и укључује три скале: персонално изгарање, изгарање на раду и клијент изгарање. У овом истраживању ће бити коришћен део скале који се односи на изгарање на раду и он се састоји од седам питања, на која испитаници могу изабрати један од пет понуђених одговора: за прва три (нпр. „Да ли је Ваш посао емоционално исцрпљујући?“) испитаници бирају један од следећих могућих одговора: веома високог степена, високог степена, ту и тамо, 
ниског степена и веома ниског степена, a за преостала четири питања (нпр. „Да ли осећате да сте сваким радним сатом на послу све уморнији?“) понуђени су следећи одговори: увек, често, повремено, ретко и никад / скоро никад.

Методе статистичке обраде података се примењују у свим истраживањима. За опис нумеричких обележја користи се: аритметичка средина и модус, а од мера варијабилитета стандардна девијација и стандардна грешка, као и минимална и максимална вредност. У табелама се представљају, у зависности од потребе приказивања резултата, апсолутне и релативне вредности. У анализи резултата, у зависности од природе самих варијабли, користи се Пирсонов хи-квадрат тест за поређење разлике између учесталости код непараметарских обележја. Код непараметарских обележја користи се Спирманов коефицијент корелације, а за проверу разлика просека између различитих параметарских резултата тестова користи се Студентов т-тест за два независна. У анализи међузависности користе се методе једноструке и вишеструке корелације и регресије. У свим примењеним аналитичким методама за ниво значајности дефинисана је вредност 0,05. За формирање базе и обраду података биће употребљен софтверски пакет SPSS - 18.0.

Очекивани резултати истраживања представљаће допринос процени интензитета доживљавања стреса и препознавања појединих стресора радника и дефинисању начина како ти стресори утичу на морбидитет испитаника и њихову способност да удовоље својим радним задацима. Употреба ових упитника омогућава упоређивање добијених резултата са резултатима истраживања осталих истраживача, код нас и у свету. Истраживања која су до сада спровођена код нас и у свету се упоређују и даје се коментар о томе.

\section{ЗАКЉУЧАК}

Неке професије су нешто више изложене стресу и већ дуже време су предмет истраживања: њихови радни услови, појава стреса и његов утицај на њихово здравље. Списак професија код којих постоји утицај стреса на здравље радника није коначан, јер је процес доказивања о присуству професионалног стреса и његовом штетном утицају на здравље у неким професијама у току. Неопходно је да специфични радни услови, појава стреса и његов утицај на њихово здравље буду предмет опсежнијих истраживања, са посебно дизајнираним упитницима. $\mathrm{He}$ могу се сви упитници користити код било које радне популације, јер се и фактори који доводе до појаве стреса разликују и по врсти, по интензитету и по трајању. Неопходно је да се сет упитника прилагоди за одговарајуће врсте делатности, тако да поред општих упитника, буду коришћени и они који дају прецизне резултате приликом процене стреса у појединим професијама. Употреба одговарајуће групе упитника код истраживања професионалног стреса код радника запослених на радним местима са повећаним ризиком по здравље омогућава добијање валидних резултата и омогућава упоређивање добијених резултата са резултатима истраживања осталих истраживача код нас и у свету. 


\section{ЛИТЕРАТУРА}

1. Павичевић Л, Бобић Ј. Стрес на раду.

У: Шарић М, Жушкин Е, ур., Медицина рада и околиша. Загреб, Медицинска наклада, 2002; 530-37.

2. Закон о безбедности и здрављу на раду. „Сл. гласник РС“, број 101/2005.

3. Правилник о начину и поступку процене ризика на радном месту и у радној околини. „Службени гласник РС”, број 72/2006.

4. Закон о раду, „Сл. гласник РС“, број 24/2005, 61/2005, 54/2009, 32/2013 и $75 / 2014$.

5. Каличанин П, Лечић-Тошевски Д. Књига о стресу. Медицинска књига, Београд, 1994.

6. Elo AL, Leppanen A, Lindstrom K, Ropponen T. Occupational Stress Quesstionnaire: User's instruction.
Helsinki:Finnish Institute for Occupational Health; 1992.

7. ILO / ICN / WHO / PSI. Workplace Violence in the Health Sector. Country Case Studies. Question Guidelines for Focus Group Discussion. Geneva; 2003.

8. Guidelines for Protecting the Safety and Health of Health Care Workers. Publication No.88-119 DHHS(NIOSH); 1988.

9. Савић С, Станковић М. Теорија система и ризика. Факултет заштите на раду у Нишу, Универзитет у Нишу, 2010. 10. Ilmarinen J, Tuomi K, Klockars M. Changes in the work ability of activeemployees over an 11-year period. Scand J Work Environ Health, 1997; 23(1): 49-57.

11. Ilmarinen J, Rantanen J. Promotion of work ability during ageing. Am J Ind. Med, 1999; 38(1): 21-3.

Контакт: Доц. др Љиљана Кулић, Универзитет у Приштини, Медицински факултет, Косовска Митровица. 